\title{
Group N Streptococcal Phage Lysin
}

\author{
BY B. REITER AND J. D. ORAM \\ National Institute for Research in Dairying, Shinfield, Reading
}

Two stages of phage multiplications, the adsorption-penetration process and the lysis of the host, have recently been largely elucidated. For some time it has been postulated that an enzyme attached to, or contained in, the phage tail is involved in the adsorption process with at least some phage-host systems. Similarly, the earliest discovered effect of a lytic phage, namely the liberation of the mature phage particles (lysis of the host), is due to a lytic enzyme acting on the cell wall. Bronfenbrenner \& Muckenfuss (1927) recognized that phage lysates contain a substance other than phage. This 'ferment-like' substance differed from phage because it only affected dead staphylococci. It was adsorbed to clay filters, inactivated on standing at room temperature, it was more heat labile than phage, and did not diffuse through collodion membranes. This description adequately fits the staphylococcal virolysin (or phage lysin) described by Ralston, Beer, Lieberman \& Krueger (1955) which lysed only dead cells, although viable cells were lysed in the presence of the homologous phage.

Brown (1956) showed that phage-free lysates of coliphage $T_{6}$ could dissolve cells of Escherichia coli killed with chloroform, and Koch \& Jordan (1957) demonstrated a free enzyme in $T_{2}$ phage lysates. Koch \& Dreyer (1958) came to the conclusion that the phage lysin was a lysozyme. This was confirmed by Weidel \& Katz (1961) and Katz \& Weidel (1961) who purified both the bound and free coli $\mathrm{T}_{2}$ phage enzymes; and Murphy (1960), working on similar lines, found that the bound and free 'megaterium' enzymes differed only in their pH optima.

Halo formation was observed by Naylor \& Czulak (1956) with a lactic acid streptococcal phage, and by Murphy $(1957 ; 1960)$ with Bacillus megaterium phage. They found that halos were due to an enzyme affecting the dead cells surrounding the phages without giving complete lysis. Murphy demonstrated that the enzyme was resistant to trypsin, pepsin, DNA-ase and RNA-ase but was inactivated by chymotrypsin. It is possible that the inhibition of a rhizobium phage by chymotrypsin reported by Kleczkowsky \& Kleczkowsky (1954) may be due to the inhibition of a similar phage enzyme. Halo formation due to cell-wall lysis differs from the halos observed around plaques of mucoid strains of Escherichia coli by Sertic (1929), and since reported to occur with many other organisms. In these cases the halo is due to an enzyme hydrolysing capsular polysaccharides (Adams \& Park, 1956).

Other aspects of the action of phage lysin are the 'nascent' phage phenomenon and 'lysis from without'. Nascent phage was first observed by Evans (1934) and shown by Maxted (1957) to be due to an enzyme liberated from the host at the same time as the phage. When some phages, e.g. coliphage $\mathbf{T}_{2}$, are adsorbed to their host 
at high multiplicity the cell wall can become so riddled with holes that the rigid structure collapses leading to 'lysis from without' (Weidel, 1951, 1958; Delbrück, 1940).

The contribution now presented is concerned with the enzyme found in phage lysates of group $\mathbf{N}$ streptococci and some aspects of phage and enzyme adsorption.

\section{Purification and properties of phage lysin}

In the first instance the enzyme was purified from high titre phage lysates of Streptococcus lactis ML $3\left(10^{12}\right.$ phage/ml.) by conventional methods-precipitation with acetone and salts and ion-exchange chromatography on Amberlite CG 50. Five hundred-fold purification was achieved with a yield of about $13 \%$ and no further purification could be obtained using a variety of fractionation procedures. A $10^{-4}$ dilution of this enzyme preparation lysed $4 \times 10^{8}$ viable cells $/ \mathrm{ml}$. in $0 \cdot 1 \mathrm{M}$ phosphate buffer at pH 6.7 at $37^{\circ}$ in $10 \mathrm{~min}$. The enzyme was heat labile and appeared most active in the presence of $0.15 \mathrm{M}$-monovalent cations and at a $\mathrm{pH}$ of 6.6-6.9, conditions which are very similar to those for optimal phage adsorption.

This phage lysin resembled that of group C streptococci (Maxted, 1957), in lysing viable cells. It thus differed from all other known lysins since these are active only against cell walls or denatured cells. Lysis of viable cells was preceded by a lag period whose length varied inversely with the initial enzyme concentration; no delay was observed with cell-wall preparations.

The action of phage lysin on cell walls resulted in the almost complete solubilization of the walls, with the release of at least two components. One, not dialysable, contained all the sugars (rhamnose, glucose and galactose), about $80 \%$ of the amino sugars (muramic acid and glucosamine) and amino acids (glutamic acid, aspartic acid, lysine and alanine). The other was dialysable and, after acid hydrolysis, was found to contain the same amino sugars and amino acids. These would appear to be present in an amino sugar-peptide complex.

Dialysable acetyl amino sugar-peptide complexes were found after the action of either lysozyme or an enzyme from Streptomyces albus on walls of Micrococcus lysodeikticus by Ghuysen \& Salton (1960) and Bacillus megaterium км (Ghuysen, 1961). However, Maxted \& Gooder (1958) failed to find low molecular weight compounds after the lysis of group A streptococcal cell walls with a group $\mathbf{C}$ streptococcal phage lysate. The release of dialysable substances from cell walls by this type of enzyme may depend on the number of secondary linkages between the muramatepeptide side chains of the amino sugar 'backbones'. These could be in the form of peptide bonds between neighbouring side chains, or links between the side chains and groups in adjacent polymers-of amino sugars or teichoic acids for example. Fewer diffusible products would be obtained by the action of enzymes on the more extensively cross-linked structures.

The effect of phage lysin on cell walls of group $\mathbf{N}$ streptococci appears to be very similar to that of lysozyme on Micrococcus lysodeikticus walls. The results are consistent with the breaking of glycosidic linkages between $N$-acetyl amino sugarpeptide compounds, some of which are not cross-linked. 


\section{Strain and group specificity}

At an early stage it was evident that the ML 3 phage lysin was not strain specific although all strains of group $\mathbf{N}$ streptococci were lysed, the rate of lysis differed appreciably. Strains of group $\mathbf{D}$ were lysed at a lower rate and strains of groups A, B and $\mathrm{C}$ were not lysed. These findings correlate well with the results of Maxted (1957) who reported lysis of group A, B, C and E streptococci, and under certain circumstances of group $\mathrm{H}$, by a phage lysate of a strain of group $\mathrm{C}$. It appears therefore that two or more types of streptococcal phage lysin occur.

Further evidence of the lack of strain specificity was obtained when a second phage lysin, prepared from a phage unrelated strain Streptococcus lactis clo was compared with the first. Although they had the same $\mathrm{pH}$ optima for activity and resistance to inactivation by heat, and had almost identical activation energies of $28 \mathrm{kcal}$. mol. ${ }^{-1}$, their activity spectra were different.

Ralston, Beer, Lieberman \& Krueger (1961) demonstrated that staphylococcal phage lysin is produced during maturation of the phage particles. Using a lactic acid streptococcus (ML 3), susceptible to two phages (ML3: large plaques; 712': minute plaques), we found that the two separately produced lysins had distinct patterns of activity against a number of test strains. This suggests that the specificity of phage lysin is determined by the phage.

\section{Inhibition of phage lysin}

Crude phage enzyme preparations readily lysed viable cells of phage unrelated strains, but not the host itself (in buffer) until the residual phage was removed by repeated centrifugation. Addition to purified enzyme preparations of the homologous phage at a multiplicity of 30-50 resulted in complete inhibition of activity. This behaviour contrasts with that of staphylococcal and megaterium lysins, in that these lyse viable cell suspensions only in the presence of their homologous phages (Ralston et al. 1955; Murphy, 1957).

Inhibition of phage lysin by phage indicates that phage and enzyme compete for adsorption sites that are either identical or very closely linked. Heterologous phages failed to inhibit the phage lysin, although so far every phage has been adsorbed by every strain. Heterologous phages must therefore be adsorbed on different sites. At $0^{\circ}$ both homologous and heterologous phages are eluted by nutrient medium whose electrolyte concentration is above that permitting adsorption. At $30^{\circ}$ no elution occurs. Phage-resistant mutants of these streptococci adsorb their phages; in this they resemble the behaviour of $\mathbf{T}_{\mathbf{1}}$ phage-resistant mutants of Escherichia coli strain $\mathrm{B}$.

Reiter \& Oram (1962) showed that suramin inhibits phage adsorption and now, as one would predict, we have found that suramin similarly inhibits phage lysin. As non-specific adsorption is also inhibited it appears that suramin masks the whole cell surface.

Escherichia coli B has been the subject of most of the research on phage receptor sites and their isolation (Weidel, 1958). It may well be that the relatively simple cell walls of the Gram-positive cocci will provide valuable additional material. 


\section{REFERENCES}

Adams, M. H. \& Park, B. H. (1956). An enzyme produced by a phage-host cell system. II. The properties of the polysaccharide depolymerase. Virology, 2, 719.

Bronfenbrenner, J. \& Muckenfuss, R. S. (1927). Studies on the bacteriophage d'Herelle. VIII. The mechanism of lysis of dead bacteria in the presence of bacteriophage. J. exp. Med. 45, 887 .

Brown, A. (1956). A study of lysis in bacteriophage infected Escherichia coli. J. Bact. 71, 482.

Delbrück, M. (1940). Adsorption of bacteriophage and lysis of the host. J. gen. Physiol. 23,643 .

Evans, A. C. (1934). Streptococcus bacteriophage: a study of four serological types. Publ. Hlth Rep., Wash. 49, 1386.

GhuYsen, J. M. (1961). Complexe acide teichoique-mucopeptide des parois cellulaires de Bacillus megaterium км. Biochim. biophys. Acta, 50, 413.

Ghuysen, J. M. \& Salton, M. R. J. (1960). Acetyl-hexosamine compounds enzymatically released from Micrococcus lysodeikticus walls. I. Isolation and composition of acetylhexosamine and acetyl-hexosamine-peptide complexes. Biochim. biophys. Acta, 40, 462.

Katz, W. \& Weidel, W. (1961). Reinigung und Charakterisierung des an $\mathbf{T}_{2}$-Phage gebundenen Lysozyms. $Z$. Naturf. $16 \mathrm{~b}, 363$.

Kueczowsky, J. \& Kleczkowsky, A. (1954). A study of the mechanism of inhibition of bacteriophage multiplication by chymotrypsin. J. gen. Microbiol. 10, 285.

Косн, G. \& Dreyer, W. J. (1958). Characterization of an enzyme of phage $\mathbf{T}_{2}$ as a lysozyme. Virology, 6, 291.

Koch, G. \& Jordan, E. (1957). Killing of $\boldsymbol{E}$. coli в by phage free $\mathbf{T}_{2}$ lysates. Biochim. biophys. Acta, 25, 437.

Maxted, W. R. (1957). The active agent in nascent phage lysis of streptococci. J. gen. Microbiol. 16, 584 .

Maxted, W. R. \& Gooder, H. (1958). Enzymatic lysis of group A streptococci. J. gen. Microbiol. 18, xiii.

MurPhy, J. S. (1957). A phage-associated enzyme of Bacillus megaterium which destroys the bacterial cell wall. Virology, 4, 563.

MurPhy, J. S. (1960). An agent derived from B. megaterium phage G which dissolves the bacterial cell wall. Virology, 11, 510.

Naylor, J. \& Czulak, J. (1956). Host-phage relationship of cheese starter organisms. II. Effect of phage activity on heterologous strains of lactic streptococci. J. Dairy Res. 23, 126.

Ralston, D. J., Beer, B., Lieberman, M. \& Krueger, A. P. (1955). Virolysin: a virus induced lysin from staphylococcal phage lysates. Proc. Soc. exp. Biol., N.Y. 89, 502.

Ralston, D. J., Beer, B., Lieberman, M. \& Krueger, A. P. (1961). Virolysin: a virusinduced lysin: its appearance and function in phage-infected staphylococci. $J$. gen. Microbiol. 24, 313.

Reiter, B. \& Oram, J. D. (1962). Inhibition of a streptococcal bacteriophage by suramin. Nature, Lond. 193, 651.

Sertic, V. (1929). Origine de la lysine d'une race du bacteriophage. C.R. Soc. Biol., Paris, $100,47 \%$.

Werdel, W. (1951). Über die Zellmembran von $E$. coli B: Präparierung der Membranen gegenüber den Bakteriophagen. Z. Naturf, 66, 251.

WEIDEL, W. (1958). Bacterial viruses (with particular reference to adsorption-penetration). Annu. Rev. Microbiol. 12, 27.

WEIDEL, W. \& KATz, W. (1961). Reindarstellung und Charakterisierung der für die Lyse $\mathrm{T}_{2}$-infizierter Zellen verantwortlichen Enzyme. $Z$. Naturf. 16 b, 156. 